Article

\title{
Inorganic geochemistry of crude oils of Northern Eurasia after ICP-MS data as a clear evidence for their deep origin
}

\author{
Kirill S. Ivanov ${ }^{1}$, Yuriy V. Erokhin ${ }^{1}$ and Daniil A. Kudriavtcev ${ }^{1, *}$ \\ 1 The Zavaritsky Institute of Geology and Geochemistry of the Ural Branch (UB) of the Russian Academy of \\ Sciences (RAS); ivanovks@igg.uran.ru and erokhin-yu@yandex.ru \\ * Correspondence: daniillkoudryavtsev@gmail.com;
}

\begin{abstract}
Emerging of mass-spectroscopy with inductively-coupled plasma (ICP-MS) made it possible to study the microelement composition of crude oil and its derivatives (with the limit of detection at the ppt level). We have studied the crude oil composition of some West Siberian and Tatarstan oilfields with the ICP-MS method to detect 50 rare, rare-earth, and other microelements. The elemental composition is reasonably comparable to their concentrations in ultrabasites whereas the contents of most of the elements are low to the limit. On the diagrams of rare-earth elements, one can see the prevalence of light lanthanides and positive europium anomaly. The study shows that crude oils have a specific microelement composition that stands out from other geological systems.
\end{abstract}

Keywords: North Eurasia, crude oil, geochemistry, ICP-MS method, microelement composition, rare-earth elements

\section{Introduction}

The growing development of analytical instruments brings geochemical research to a qualitatively new level. With the introduction of inductively coupled plasma mass spectrometry (ICP-MS), it became possible to study the trace element composition not only of rocks but also of such complex mixtures as crude oil and other petroleum systems. ICP-MS is one of the most advanced mass spectroscopy techniques due to its high sensitivity and the ability to perform multi-element determination in a single analysis. During the present study, we were able to investigate the trace element composition of various crude oils by the ICP-MS method for a wide range (more than 50) of rare, rareearth, and other elements. The crude oil samples were taken from different regions of the two main Russian oil-producing provinces - Western Siberia (the fields of Shaimsky, Sredneobsky, and Oktyabrsky regions) and Tatarstan.

ICP-MS doesn't show in which compounds the microelements occurred, but with the evidence of $[7,17]$ we could assume that most of the trace elements are part of the organometallic compounds - porphyrins $(\mathrm{V}, \mathrm{Ni})$, salts of organic acids $(\mathrm{Cu}, \mathrm{Zn}, \mathrm{Ge}, \mathrm{Au})$, as well as colloidal $(\mathrm{V}, \mathrm{Fe}, \mathrm{NaCl})$ and real $(\mathrm{Cu}, \mathrm{Fe}, \mathrm{Pb}, \mathrm{U})$ solutions adsorbed on the active oil/water surface ( $\mathrm{Zn}, \mathrm{Cu}, \mathrm{Ni}, \mathrm{U}, \mathrm{Ca}, \mathrm{Mg}, \mathrm{Fe}, \mathrm{V})$. Porphyrin metal complexes, as well as the main part of metal-containing petroleum compounds, are concentrated in resinousasphaltene fractions and heavy oil residues [14].

\section{Materials and Methods}

The analysis was carried out using an ELEMENT 2 high-resolution mass spectrometer according to the methodology developed at the IGG UB RAS (Institute of 
geology and geochemistry, Ural branch of Russian Academy of Sciences) by Yu.L. Ronkin scientific group [12].

The decomposition of crude oil was carried out with a mixture of high-purity acids ( $\mathrm{HNO} 3, \mathrm{HCl})$ and hydrogen peroxide $\mathrm{H} 2 \mathrm{O} 2$ in a Multiwave 3000 microwave oven manufactured by Anton Paar GmbH (Austria) with an 8XQ80 rotor (8 quartz reaction vessels, $80 \mathrm{ml}$ each), which makes it possible to implement quite severe experimental conditions (maximum temperature and pressure $-300{ }^{\circ} \mathrm{C}$ and $120 \mathrm{~atm}$ ). The chemical preparation of the samples was carried out in a "clean" room, the water for the experiments was additionally purified twice by the "subboiling" method. Contamination levels were assessed for each reagent and monitored during analysis.

Determination of the 59 chemical elements mass fraction in the analyzed samples was carried out using a high-resolution sector tandem mass spectrometer with ionization in inductively coupled plasma HRICP-MS Element2 manufactured by Thermo Scientific (Bremen, Germany). The measurements were carried out with the following parameters: 1) spray gas flow - $0.80 \mathrm{l} / \mathrm{min}$; 2) plasma-forming flow - $0.85 \mathrm{l} / \mathrm{min}$; 3) cooling flow - 16 $1 / \mathrm{min}$; 4) high-frequency power of the plasma generator - $1050 \mathrm{~W}$; 5) voltage on a twostage (with automatic calibration of analog and counting components) detector - $2500 \mathrm{~V}$. The measurement technique involved daily verification of the instrument's sensitivity, establishing a calibration dependence for the entire mass scale using six solutions certified for the content of elements: 1) U, Th; 2) Y, Zr, Sc, La, Ce, Pr, Nd, Sm, Eu, Gd, Tb, Dy, Ho, Er, Tm, Yb, Hf; 3) Be, Mg, Al, Ca, V, Cr, Mn, Fe, Ni, Cu, Zn, Ga, As, Se, Sr, Cd, In, Ba, Tl, $\mathrm{Pb}, \mathrm{Bi}$; 4) B, P, Ti, Go, Nb, Mo, Ta, W, Re; 5) Na, K, Rb, Cs; 6) Ag.

Based on the results of the standard solutions measured intensities using the MS standard software, the dependences were plotted in the coordinates "signal intensity concentration". These dependencies were further used to calculate the concentrations of elements in real samples. Double accounting of possible errors allows analysis of 59 elements with an accuracy $\pm(8-10) \%$ rel. It is important to note that only the instrumental error is meant here. Errors associated with possible contamination of the sample during the sampling process, "under-decomposition" of the sample (typical, for example, for Cr), or with the non-representativeness of the sample. An internal standard (Rh) was used to account for the interelement and sample matrix effects. The influence of spectral overlays in the mass spectrometric determination of elements was taken into account by the software method of mathematical correction. After measuring the next 10 analyzed samples, the calibration solution was measured and, in case of significant deviations from the previous calibration, a complete re-calibration was performed. Quality control of the obtained results was carried out employing parallel analyzes of internal verification samples and a multielement standard sample Conostan S-21 (Conostan, USA, www.conostan.com), intended for measuring the mass fraction of metals in crude oil and crude oil derivatives.

\section{Results.}

\subsection{Inorganic chemistry of West-Siberian oil and gas megabasin}

Shaimsky district. Information about the geology and oil-bearing capacity of the area has been published in various works $[1,4,9,11]$. In the Shaim oil and gas region, we have analyzed petroleum systems from wells in eight areas - Severo-Danilovskaya, Danilovskaya, Dorozhnaya, Ust-Teterevskaya, Ubinskaya, Lovinskaya, Tolumskaya, and Mortymya-Teterevskaya. The results are shown in Table 1.

The main geochemical feature of Shaim crude oil, as well as crude oils from other regions, is the extremely low content of elements. Thus, when normalized to the primitive mantle, the ultrabasites depleted in most trace elements give a distribution in the region of 0.1 units, and crude oil in the region of 0.001 . Ultramafic rocks contain about 10 times fewer trace elements than the primitive mantle, and crude oil - 1000 times less. As an 
example, we note that the contents of trace elements in the Triassic basalts of Western Siberia exceed the contents in the primitive mantle by a factor of 10 (see Figure 1), and these basalts are from the same Shaimsky region, where the crude oil we have analyzed was taken.

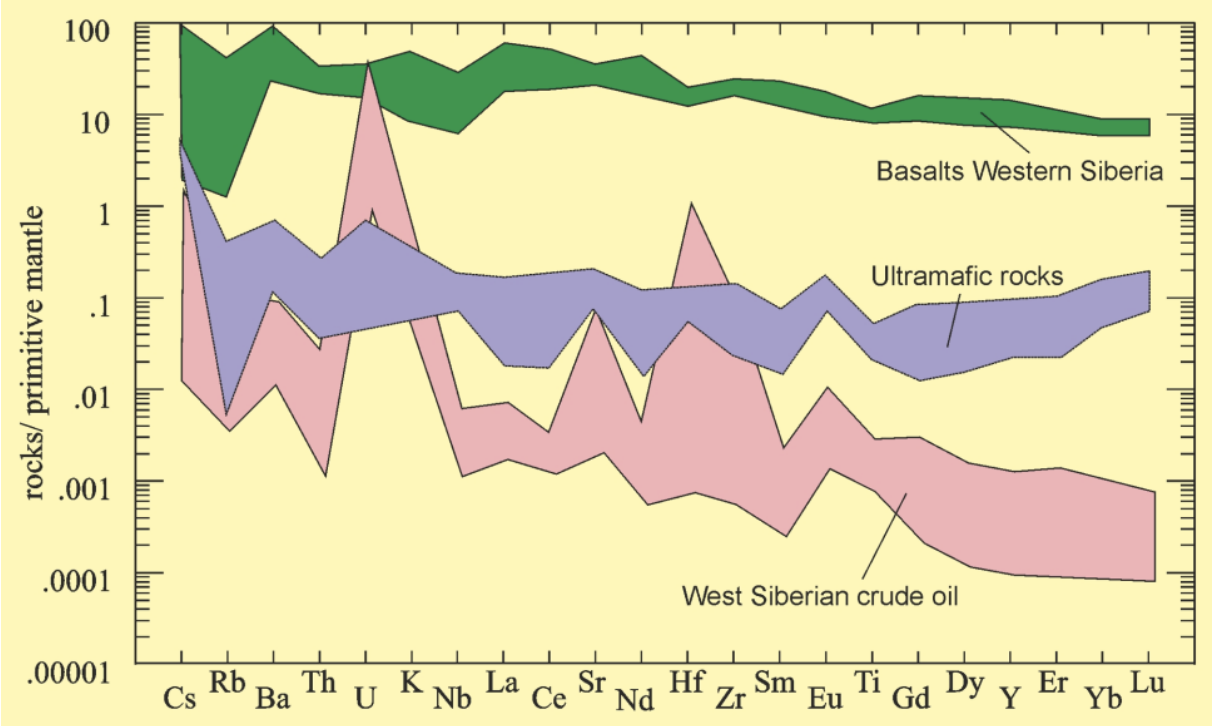

Figure 1. Spider-diagram normalized by the composition of the primitive mantle [18] for Priuralskaya crude oil (West Siberia).

In the crude oil of the Shaim region, a certain group of trace elements is distinguished by relatively high contents (more than $1 \mathrm{ppm}$; see Table 1 ), mainly petrogenic components $(\mathrm{Mg}, \mathrm{Al}, \mathrm{Fe}, \mathrm{Na}, \mathrm{Ti})$, and transit elements $(\mathrm{Cr}, \mathrm{V}, \mathrm{Ni}, \mathrm{Cu}, \mathrm{Zn})$. On the $\mathrm{Ni}-\mathrm{Cu}-\mathrm{Cr}$ diagram (for resinous-asphaltene fractions) proposed by A.A. Marakushev and colleagues [6] Shaim oil belongs to the chromium type (see Figure 2), falling on the continuation of the trend outlined by these authors of the West Siberian province. The rest of the trace elements in the crude oils of the Shaim region are characterized by low contents $(<1 \mathrm{ppm}$; see Table 1), but often higher than in some rocks. For individual components (cesium, rubidium, strontium, zirconium), the content of elements in crude oils is quite comparable with their contents in ultrabasites. At the same time, the concentration of uranium in crude oils is significantly higher than in ultrabasites, chondrites, and medium rocks (according to [3]). The appearance of such an amount of uranium in crude oils can be explained by the reducing conditions of the environment and by the presence of a geochemical barrier. As a result, high content of lead is also recorded in hydrocarbons (up to $0.3 \mathrm{ppm}$ ). The silver content in the Shaim oil was also quite high (up to $0.1 \mathrm{ppm}$ ), and the amount of gold was low (no more than $0.002 \mathrm{ppm}$ ). 


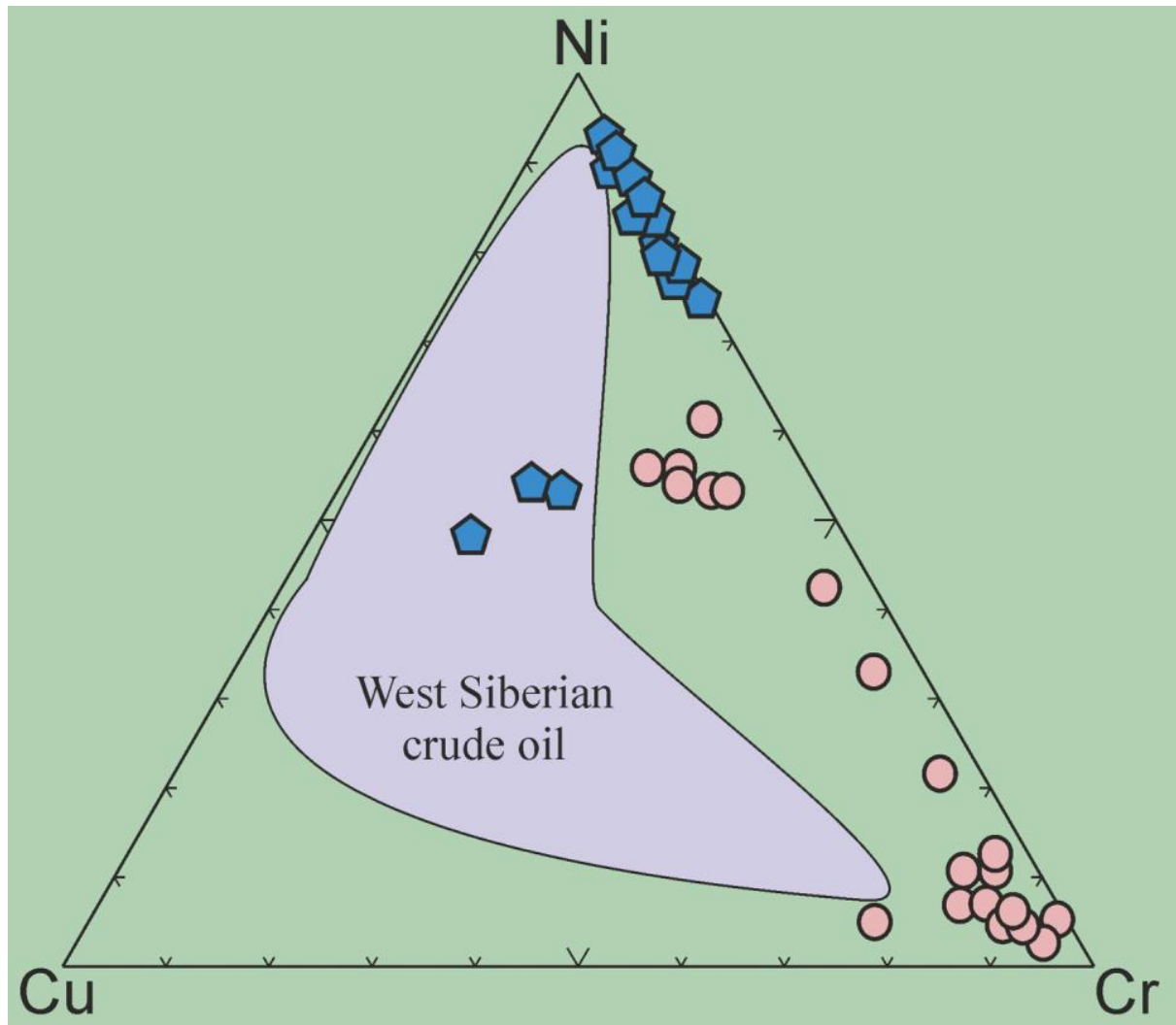

Figure 2. Taxonomy of crude oil fields by the content of nickel, copper and chromium in crude oils. Note: the field shows the West Siberian province [6]. Our data: the circles crude oils of the West-Siberian Urals part, pentagons - Tatarstan.

Table 1. Results of ICP-MS (in ppm) for crude oil of Shaimsky district

\begin{tabular}{|c|c|c|c|c|c|c|c|c|}
\hline $\begin{array}{l}\text { Elemen } \\
\text { ts }\end{array}$ & 1 & 2 & 3 & 4 & 5 & 6 & 7 & 8 \\
\hline $\mathrm{Li}$ & - & - & - & 0.00268 & 0.00550 & 0.00448 & 0.00753 & 0.00089 \\
\hline $\mathrm{Be}$ & 0.00037 & 0.00386 & 0.00311 & 0.00068 & 0.0009 & 0.0008 & 0.00036 & 0.00036 \\
\hline B & 0.00058 & 0.00073 & 0.00066 & 0.05321 & 0.13300 & 0.06020 & 0.06500 & 0.04371 \\
\hline $\mathrm{Mg}$ & 0.72588 & 13.8547 & 12.4009 & 0.47086 & 0.91731 & 0.56882 & 0.39074 & 0.71989 \\
\hline $\mathrm{Al}$ & 0.15236 & 9.5214 & 8.27537 & 1.12454 & 1.37350 & 1.01343 & 1.09291 & 1.84287 \\
\hline Sc & 0.00296 & 0.15687 & 0.13227 & 0.11998 & 0.11444 & 0.10873 & 0.17218 & 0.14430 \\
\hline
\end{tabular}




\begin{tabular}{|c|c|c|c|c|c|c|c|c|}
\hline $\mathrm{Ti}$ & 0.01347 & 0.97335 & 0.87796 & 2.89765 & 2.74938 & 2.35654 & 3.56146 & 1.78890 \\
\hline V & 3.3540 & 0.17643 & 1.31451 & 10.4498 & 11.6318 & 8.8610 & 9.3321 & 6.4884 \\
\hline $\mathrm{Cr}$ & 14.5428 & 5.29674 & 10.8183 & 28.4995 & 32.7446 & 28.6782 & 17.2258 & 25.5459 \\
\hline $\mathrm{Mn}$ & 0.02083 & 0.15319 & 0.12857 & 0.11641 & 0.59776 & 0.11036 & 0.16766 & 0.63659 \\
\hline $\mathrm{Fe}$ & 5.033 & 49.0878 & 43.733 & 52.1724 & 48.9204 & 35.9154 & 38.3182 & 35.9450 \\
\hline Co & 0.00153 & 0.00851 & 0.00473 & 0.01246 & 0.00702 & 0.07782 & 0.09166 & 0.00702 \\
\hline $\mathrm{Ni}$ & 0.91805 & 0.41504 & 1.03197 & 10.1142 & 4.57676 & 17.0646 & 14.7218 & 3.12589 \\
\hline $\mathrm{Cu}$ & 0.00146 & 1.36885 & 1.35712 & 1.77310 & 2.06376 & 1.67553 & 1.83192 & 1.93616 \\
\hline $\mathrm{Zn}$ & 0.18462 & 1.36437 & 1.48157 & 4.98010 & 5.84579 & 6.30084 & 4.85887 & 11.7174 \\
\hline $\mathrm{Ga}$ & 0.05859 & 0.00541 & 0.00827 & 0.15353 & 0.15572 & 0.13375 & 0.04740 & 0.12771 \\
\hline As & 0.52042 & 0.17214 & 0.09681 & 0.6819 & 0.83962 & 0.78702 & 0.58810 & 0.66959 \\
\hline $\mathrm{Rb}$ & 0.02364 & 0.05573 & 0.02794 & 0.00194 & 0.00696 & 0.00255 & 0.01205 & 0.01118 \\
\hline $\mathrm{Sr}$ & 0.05428 & 0.09392 & 0.47156 & 0.21142 & 0.65098 & 0.46156 & 0.58319 & 1.69799 \\
\hline Y & 0.00089 & 0.00107 & 0.00039 & 0.00041 & 0.00104 & 0.00069 & 0.00087 & 0.00079 \\
\hline
\end{tabular}




\begin{tabular}{|c|c|c|c|c|c|c|c|c|}
\hline $\mathrm{Zr}$ & 0.00658 & 0.85219 & 0.44027 & 0.12356 & 0.20415 & 0.10810 & 0.10668 & 0.12442 \\
\hline $\mathrm{Nb}$ & 0.00078 & 0.00159 & 0.00122 & 0.00210 & 0.00408 & 0.00313 & 0.00203 & 0.00338 \\
\hline Mo & 0.1691 & 0.13347 & 0.11708 & 0.09874 & 0.05995 & 0.05183 & 0.05682 & 0.05256 \\
\hline $\mathrm{Ru}$ & \begin{tabular}{|l|}
0.0008 \\
\end{tabular} & 0.00717 & 0.00568 & 0.00329 & 0.00580 & 0.00226 & 0.00411 & 0.00509 \\
\hline $\mathrm{Rh}$ & 0.00122 & 0.00024 & 0.00022 & 0.00027 & 0.00016 & 0.00009 & 0.00051 & 0.00033 \\
\hline $\mathrm{Pd}$ & 0.00216 & 0.03744 & 0.01931 & 0.01056 & 0.01635 & 0.00820 & 0.00952 & 0.01052 \\
\hline $\mathrm{Ag}$ & 0.01075 & 0.00098 & 0.00421 & 0.00416 & 0.00296 & 0.00339 & 0.00321 & 0.00506 \\
\hline $\mathrm{Cd}$ & 0.00204 & 0.00450 & 0.00048 & 0.01396 & 0.00720 & 0.00891 & 0.00821 & 0.00967 \\
\hline In & 0.00034 & 0.00139 & 0.00216 & 0.00005 & 0.00043 & 0.00062 & 0.00044 & 0.00051 \\
\hline Sn & 0.16198 & 0.00108 & 0.38763 & 0.24998 & 0.14538 & 0.14610 & 0.27392 & 0.22622 \\
\hline $\mathrm{Sb}$ & 0.00079 & 0.00445 & 0.00285 & 0.00391 & 0.00498 & 0.00354 & 0.00204 & 0.00440 \\
\hline $\mathrm{Te}$ & 0.00109 & 0.00223 & 0.00018 & 0.00020 & 0.00033 & 0.00031 & 0.00019 & 0.00028 \\
\hline I & - & - & - & 0.17378 & 1.37407 & 0.27695 & 0.18988 & 0.09614 \\
\hline
\end{tabular}




\begin{tabular}{|c|c|c|c|c|c|c|c|c|}
\hline Cs & 0.00199 & 0.00195 & 0.00194 & 0.00028 & 0.00039 & 0.00042 & 0.00013 & 0.00007 \\
\hline $\mathrm{Ba}$ & 0.09914 & 0.19176 & 0.07979 & 0.32165 & 0.28396 & 0.14268 & 0.18009 & 0.53189 \\
\hline $\mathrm{La}$ & 0.00129 & 0.00233 & 0.00185 & 0.00237 & 0.00395 & 0.00366 & 0.00548 & 0.00358 \\
\hline $\mathrm{Ce}$ & 0.00227 & 0.00402 & 0.00295 & 0.00373 & 0.00552 & 0.00484 & 0.00645 & 0.00456 \\
\hline $\operatorname{Pr}$ & 0.00048 & 0.00053 & 0.00043 & 0.00052 & 0.00066 & 0.00048 & 0.00058 & 0.00064 \\
\hline $\mathrm{Nd}$ & 0.00194 & 0.00191 & 0.00184 & 0.00145 & 0.00271 & 0.00215 & 0.00181 & 0.00207 \\
\hline Sm & 0.00076 & 0.00059 & 0.00052 & 0.00035 & 0.00028 & 0.00047 & 0.00029 & 0.00029 \\
\hline $\mathrm{Eu}$ & 0.00168 & 0.00027 & 0.00029 & 0.00051 & 0.00040 & 0.00005 & 0.00002 & 0.00088 \\
\hline $\mathrm{Gd}$ & 0.00155 & 0.00046 & 0.00053 & 0.00049 & 0.00045 & 0.00053 & 0.00048 & 0.00040 \\
\hline $\mathrm{Tb}$ & 0.00025 & 0.00009 & 0.00006 & 0.00005 & 0.00005 & 0.00007 & 0.00010 & 0.00006 \\
\hline Dy & 0.00108 & 0.00047 & 0.00048 & 0.00029 & 0.00033 & 0.00039 & 0.00064 & 0.00029 \\
\hline Ho & 0.00023 & 0.00011 & 0.00012 & 0.00006 & 0.00006 & 0.00007 & 0.00013 & 0.00007 \\
\hline Er & 0.00059 & 0.00036 & 0.00033 & 0.00019 & 0.00019 & 0.00022 & 0.00034 & 0.00022 \\
\hline
\end{tabular}




\begin{tabular}{|c|c|c|c|c|c|c|c|c|}
\hline $\mathrm{Tm}$ & 0.0001 & 0.00004 & 0.00003 & 0.00002 & 0.00003 & 0.00003 & 0.00005 & 0.00003 \\
\hline $\mathrm{Yb}$ & 0.00053 & 0.00012 & 0.00015 & 0.00013 & 0.00019 & 0.00013 & 0.00025 & 0.00017 \\
\hline $\mathrm{Lu}$ & 0.00005 & 0.00001 & 0.00002 & 0.00002 & 0.00003 & 0.00002 & 0.00003 & 0.00003 \\
\hline Hf & 0.00458 & 0.33835 & 0.27481 & 0.01208 & 0.01260 & 0.01215 & 0.01418 & 0.01237 \\
\hline Ta & 0.00003 & 0.00165 & - & 0.00019 & 0.00006 & 0.00007 & 0.00002 & 0.00015 \\
\hline W & 0.00256 & 0.01589 & 0.00994 & 0.00870 & 0.00477 & 0.00622 & 0.00406 & 0.00769 \\
\hline $\operatorname{Re}$ & 0.00004 & 0.00567 & 0.00004 & 0.00564 & 0.00272 & 0.00400 & 0.00276 & 0.00456 \\
\hline Os & 0.00048 & 0.00017 & 0.00002 & 0.00006 & 0.00005 & 0.00018 & 0.00000 & 0.00000 \\
\hline Ir & 0.00058 & 0.00958 & 0.00622 & 0.0004 & 0.0003 & 0.00016 & 0.00004 & 0.00007 \\
\hline $\mathrm{Pt}$ & 0.00162 & 0.01378 & 0.00988 & 0.00094 & 0.00119 & 0.00081 & 0.00027 & 0.00032 \\
\hline $\mathrm{Au}$ & 0.00178 & 0.00138 & 0.00084 & 0.00039 & 0.00002 & 0.00049 & 0.00041 & 0.00029 \\
\hline $\mathrm{Hg}$ & 0.00245 & 0.02355 & 0.00373 & 0.00185 & 0.00278 & 0.01267 & 0.00549 & 0.00215 \\
\hline $\mathrm{Tl}$ & 0.00152 & 0.00125 & 0.00011 & 0.04597 & 0.03323 & 0.04428 & 0.07018 & 0.05134 \\
\hline
\end{tabular}




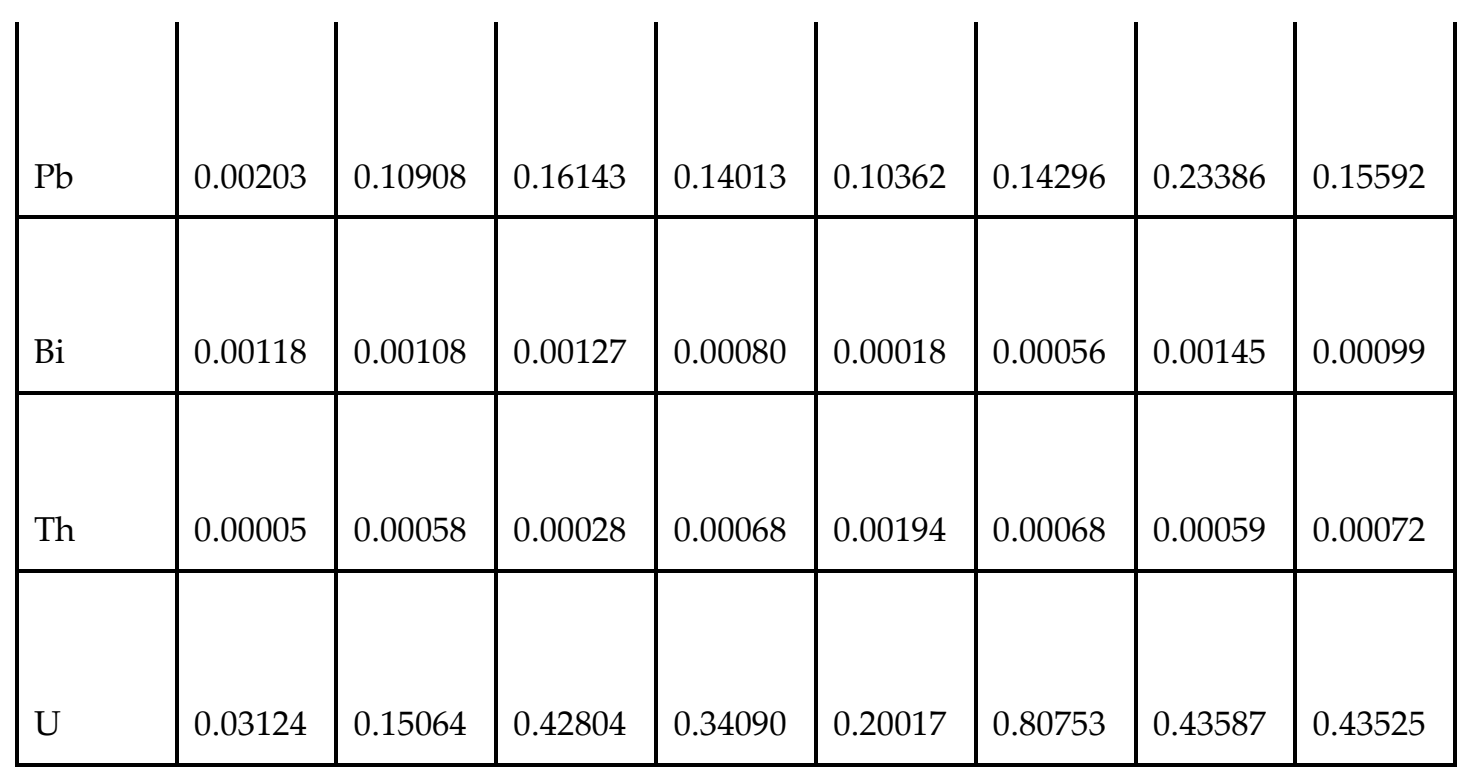

Note: hereinafter, experiments were carried out on the Element 2 by Yu.L. Ronkin, O.P. Lepikhina, O.Yu. Popova and others; 1 - Tolumskaya area (sample BPS-4), 2 Mortymya-Teterevskaya area (well 395), 3 - Lovinskaya area (well 9195), 4 - VostochnoPridorozhnoe (well 402/2), 5 - Kustovoe (well 1182/26), 6 - Povkhovskoe (well 3775/165), 7 - Vat-Yeganskoe (well 4881/106), 8 - Yuzhno-Yagunskoe (well 164r).

When normalizing the contents of trace elements in hydrocarbons to the contents in the primitive mantle (according to [16]), positive anomalies for uranium, strontium, titanium, yttrium, and zirconium, as well as negative anomalies for samarium, hafnium, thorium, niobium, and neodymium are established in the distribution (see Fig. 1). Among themselves, crude oils from different areas of the Shaim region follow a unified geochemical trend. This is especially well observed for rare and trace elements, while significant differences are already noted in the contents of rare earth elements. Rare earth elements in Shaim oils, normalized to chondrite, show one type of trend with a gradual enrichment of light lanthanides. The REE distribution spectrum is characterized by a La / $\mathrm{Yb}$ ratio of 16-19 units with the presence of a sharply positive europium anomaly and a weak negative one for samarium (for example, the Slavinskoe deposit; see Fig. 3). In addition, the composition of REE in different fractions was studied for the same crude oils. It turned out that the heaviest fractions of hydrocarbons are characterized by higher concentrations of lanthanides, while the configuration of the trends remains practically unchanged (Figure 3). 


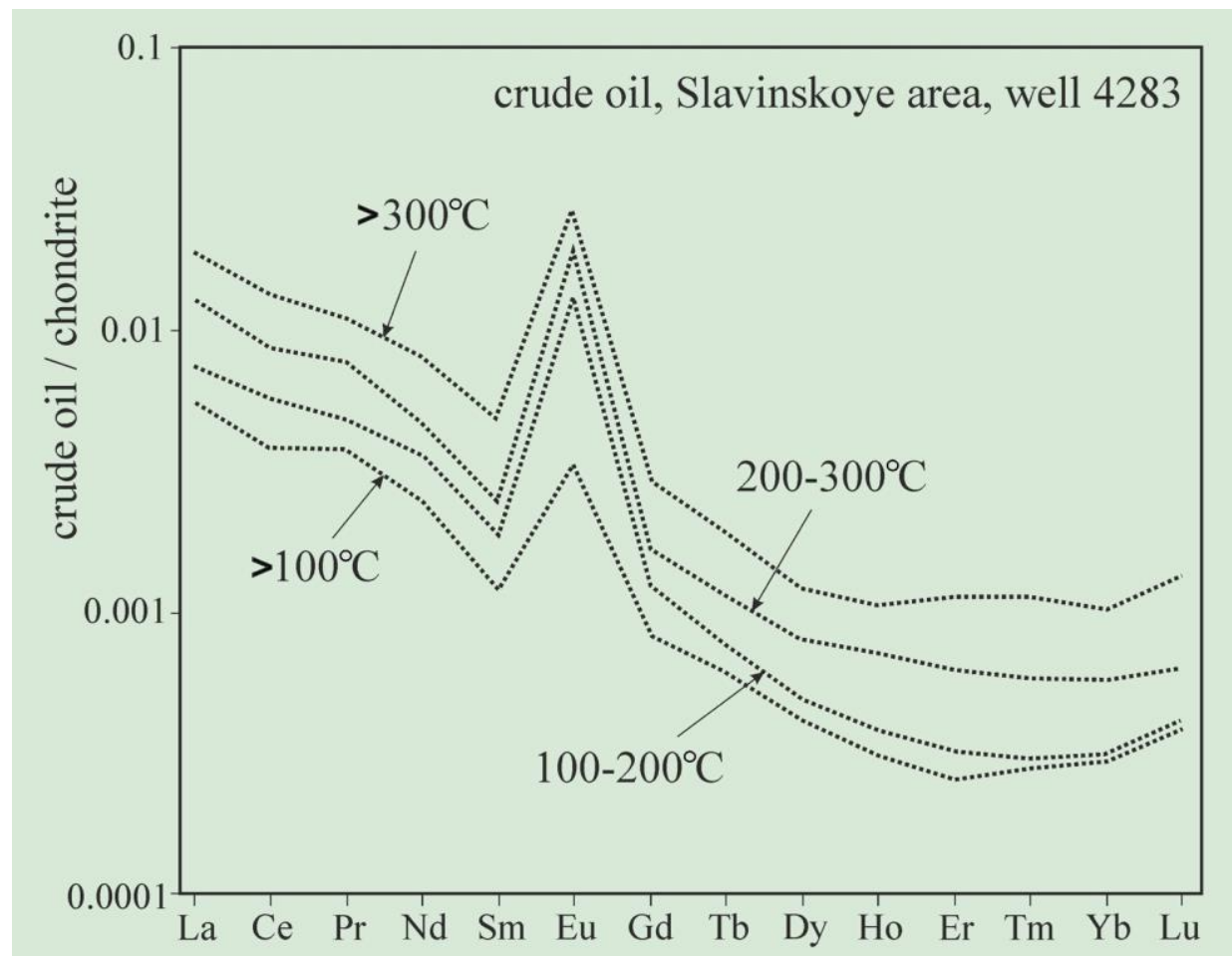

Figure 3. Distribution curves of rare earth elements normalized to chondrite [16] for crude oil of Slavinskoye oil field of Shaimsky petroleum district. The temperatures are corresponding to the crude oil fractions.

In general, the europium ratio is an indicator of redox conditions, often a positive europium anomaly characterizes a reducing environment, which is known to be typical for hydrocarbons as well. The geochemical peculiarity of europium is that its valence is variable. Under the conditions of the earth's surface, with free access of oxygen, it is trivalent (like other REE), but in the heated depths of the Earth, in the absence of free oxygen, europium is reduced to a bivalent state and becomes more mobile, passing into hydrothermal solutions circulating along the cracks of rocks. more intense than the rest of the REE. According to the most representative work [18; as well as the data of other researchers] on the distribution of rare earth elements in the section of the earth's crust, a positive europium anomaly could be characteristic of deep formations, ie. geological objects formed in the lower parts of the earth's crust and below.

Sredneobsky district. Deposits of the Sredneobsky region are located in the central part of the Khanty-Mansi Autonomous Okrug in the vicinity of Kogalym town. In total, crude oils from five different sites were analyzed. The results of measurements are shown in table 2 (1-3). In crude oils of the Sredneobsky region, a certain group of trace elements is distinguished by rather high content (more than $1 \mathrm{ppm}$ ), mainly petrogenic components $(\mathrm{Na}, \mathrm{Mg}, \mathrm{Al}, \mathrm{Fe})$ and transit elements $(\mathrm{Cr}, \mathrm{V}, \mathrm{Ni}, \mathrm{Co}, \mathrm{Cu}, \mathrm{Zn})$. The amount of light elements $(\mathrm{Li}, \mathrm{Be}, \mathrm{B})$ in the studied samples is characterized by lower concentrations and usually does not exceed $0.1 \mathrm{ppm}$. Thus, the content of lithium reaches $0.008 \mathrm{ppm}$, beryllium 0.0009 ppm, and boron - 0.13 ppm (see Table 2). 
Table 2. Results of ICP-MS (in ppm) for crude oils of Sredneobsky and Oktyabrsky district

\begin{tabular}{|c|c|c|c|c|c|c|c|c|}
\hline $\begin{array}{c}\text { Elemen } \\
\text { ts }\end{array}$ & 1 & 2 & 3 & 4 & 5 & 6 & 7 & 8 \\
\hline $\mathrm{Li}$ & 0.004 & 0.008 & 0.0009 & 0.57 & 0.38 & 0.29 & 0.23 & 0.34 \\
\hline $\mathrm{Be}$ & 0.001 & 0.0004 & 0.0004 & 0.002 & 0.002 & 0.003 & 0.002 & 0.002 \\
\hline $\mathrm{Na}$ & 200 & 3.77 & 4.37 & 525 & 970.2 & 13.12 & 87.53 & 40.35 \\
\hline $\mathrm{Mg}$ & 0.57 & 0.39 & 0.71989 & 27.87 & 17.52 & 28.52 & 13.69 & 12.20 \\
\hline $\mathrm{Al}$ & 1.01 & 1.09 & 1.84 & 36.87 & 20.81 & 34.16 & 30.97 & 20.07 \\
\hline $\mathrm{P}$ & - & - & - & 2156 & 2001 & 2452 & 1964 & 2173 \\
\hline K & - & - & - & 128 & 95.14 & 126 & 75.66 & 92.71 \\
\hline $\mathrm{Ca}$ & - & - & - & 225 & 142 & 220 & 170 & 181 \\
\hline Sc & 0.11 & 0.17 & 0.14 & 1.01 & 0.28 & 1.51 & 0.76 & 0.81 \\
\hline $\mathrm{Ti}$ & 2.36 & 3.56 & 1.79 & 45.70 & 14.82 & 18.94 & 16.37 & 19.35 \\
\hline
\end{tabular}




\begin{tabular}{|c|c|c|c|c|c|c|c|c|}
\hline $\mathrm{V}$ & 8.86 & 9.33 & 6.49 & 0.12 & 0.07 & 0.07 & 0.04 & 0.06 \\
\hline $\mathrm{Cr}$ & 28.68 & 17.23 & 25.55 & 1.59 & 0.74 & 2.19 & 1.76 & 1.88 \\
\hline $\mathrm{Mn}$ & 0.11 & 0.17 & 0.64 & 0.56 & 0.17 & 0.23 & 0.12 & 0.25 \\
\hline $\mathrm{Fe}$ & 35.92 & 38.32 & 35.95 & 70.33 & 41.13 & 79.24 & 30.36 & 61.57 \\
\hline Co & 0.078 & 0.092 & 0.007 & 0.024 & 0.017 & 0.031 & 0.011 & 0.020 \\
\hline $\mathrm{Ni}$ & 17.065 & 14.722 & 3.126 & 4.024 & 3.696 & 4.723 & 3.505 & 4.628 \\
\hline $\mathrm{Cu}$ & 1.676 & 1.832 & 1.936 & 0.173 & 1.601 & 1.029 & 0.016 & 0.264 \\
\hline $\mathrm{Zn}$ & 6.301 & 4.859 & 11.717 & 6.173 & 3.033 & 10.34 & 10.58 & 3.472 \\
\hline $\mathrm{Ga}$ & 0.134 & 0.047 & 0.128 & 0.232 & 0.104 & 0.014 & 0.019 & 0.025 \\
\hline $\mathrm{Ge}$ & - & - & - & 0.026 & 0.010 & 0.033 & 0.003 & 0.019 \\
\hline $\mathrm{Rb}$ & 0.003 & 0.012 & 0.011 & 0.020 & 0.013 & 0.027 & 0.027 & - \\
\hline $\mathrm{Sr}$ & 0.462 & 0.583 & 1.698 & 10.44 & 7.12 & 0.69 & 0.56 & 1.02 \\
\hline
\end{tabular}




\begin{tabular}{|c|c|c|c|c|c|c|c|c|}
\hline $\mathrm{Y}$ & 0.0007 & 0.0009 & 0.0008 & 0.009 & 0.004 & 0.006 & 0.017 & 0.004 \\
\hline $\mathrm{Zr}$ & 0.108 & 0.107 & 0.124 & 0.067 & 0.057 & 0.057 & 5.354 & 0.052 \\
\hline $\mathrm{Nb}$ & 0.003 & 0.002 & 0.003 & 0.007 & 0.004 & 0.004 & 0.004 & 0.026 \\
\hline Mo & 0.052 & 0.057 & 0.053 & 0.039 & 0.034 & 0.035 & 0.032 & 0.034 \\
\hline $\mathrm{Ru}$ & 0.002 & 0.004 & 0.005 & 0.002 & 0.002 & 0.003 & 0.004 & 0.003 \\
\hline $\mathrm{Rh}$ & 0.0001 & 0.0005 & 0.0003 & 0.003 & 0.002 & 0.001 & 0.001 & 0.002 \\
\hline $\mathrm{Ag}$ & 0.003 & 0.003 & 0.005 & 0.004 & 0.002 & 0.011 & 0.047 & 0.003 \\
\hline $\mathrm{Pd}$ & 0.008 & 0.010 & 0.011 & 0.0002 & 0.0002 & 0.0002 & 0.0028 & 0.0002 \\
\hline $\mathrm{Cd}$ & 0.009 & 0.008 & 0.010 & 0.007 & 0.004 & 0.011 & 0.011 & 0.004 \\
\hline In & 0.001 & 0.0004 & 0.001 & 0.002 & 0.001 & 0.002 & 0.001 & 0.002 \\
\hline Sn & 0.146 & 0.274 & 0.226 & 0.032 & 0.031 & 0.063 & 0.031 & 0.032 \\
\hline $\mathrm{Sb}$ & 0.004 & 0.002 & 0.004 & 0.018 & 0.007 & 0.049 & 0.016 & 0.056 \\
\hline
\end{tabular}




\begin{tabular}{|c|c|c|c|c|c|c|c|c|}
\hline $\mathrm{Te}$ & 0.0003 & 0.0002 & 0.0003 & 0.001 & - & 0.001 & 0.001 & 0.005 \\
\hline I & 0.27 & 0.19 & 0.10 & 9.12 & 4.39 & 2.07 & 1.63 & 1.23 \\
\hline Cs & 0.0004 & 0.0001 & 0.0001 & 0.029 & 0.006 & 0.002 & 0.001 & 0.002 \\
\hline $\mathrm{Ba}$ & 0.14 & 0.18 & 0.53 & 10.65 & 5.02 & 0.25 & 0.27 & 0.73 \\
\hline $\mathrm{La}$ & 0.0037 & 0.0055 & 0.0036 & 0.009 & 0.003 & 0.007 & 0.008 & 0.010 \\
\hline $\mathrm{Ce}$ & 0.0048 & 0.0065 & 0.0046 & 0.017 & 0.006 & 0.013 & 0.015 & 0.020 \\
\hline $\operatorname{Pr}$ & 0.0005 & 0.0006 & 0.0006 & 0.002 & 0.001 & 0.001 & 0.002 & 0.002 \\
\hline $\mathrm{Nd}$ & 0.0022 & 0.0018 & 0.0021 & 0.007 & 0.003 & 0.005 & 0.005 & 0.007 \\
\hline $\mathrm{Sm}$ & 0.00047 & 0.00029 & 0.00029 & 0.002 & 0.0005 & 0.001 & 0.001 & 0.001 \\
\hline $\mathrm{Eu}$ & 0.00005 & 0.00002 & 0.00088 & 0.009 & 0.004 & 0.001 & 0.001 & 0.0013 \\
\hline $\mathrm{Gd}$ & 0.0005 & 0.0005 & 0.0004 & 0.002 & 0.0005 & 0.001 & 0.001 & 0.001 \\
\hline $\mathrm{Tb}$ & 0.00007 & 0.00010 & 0.00006 & 0.0002 & 0.0001 & 0.0002 & 0.0002 & 0.0002 \\
\hline
\end{tabular}




\begin{tabular}{|c|c|c|c|c|c|c|c|c|}
\hline Dy & 0.00039 & 0.00064 & 0.00029 & 0.002 & 0.0004 & 0.001 & 0.0021 & 0.0013 \\
\hline Ho & 0.00007 & 0.00013 & 0.00007 & 0.0003 & 0.0001 & 0.0002 & 0.0006 & 0.0002 \\
\hline Er & 0.00022 & 0.00034 & 0.00022 & 0.0008 & 0.0002 & 0.0006 & 0.002 & 0.0007 \\
\hline $\mathrm{Tm}$ & 0.00003 & 0.00005 & 0.00003 & 0.0001 & 0.00004 & 0.0001 & 0.001 & 0.0001 \\
\hline $\mathrm{Yb}$ & 0.00013 & 0.00025 & 0.00017 & 0.001 & 0.0003 & 0.00071 & 0.0042 & 0.00071 \\
\hline $\mathrm{Lu}$ & 0.00002 & 0.00003 & 0.00003 & 0.0002 & 0.00004 & 0.0001 & 0.001 & 0.0001 \\
\hline Hf & 0.012 & 0.014 & 0.012 & 0.002 & 0.001 & 0.002 & 0.144 & 0.001 \\
\hline $\mathrm{Ta}$ & 0.0001 & 0.00002 & 0.0002 & 0.0004 & 0.0003 & 0.0003 & 0.0004 & 0.001 \\
\hline W & 0.006 & 0.004 & 0.008 & 0.032 & 0.099 & 0.024 & 0.055 & 0.029 \\
\hline $\operatorname{Re}$ & 0.004 & 0.003 & 0.005 & 0.003 & 0.007 & 0.002 & 0.003 & 0.002 \\
\hline Os & 0.0002 & - & - & 0.0001 & 0.0002 & 0.0002 & 0.0002 & 0.0004 \\
\hline Ir & 0.0002 & 0.00004 & 0.0001 & 0.0002 & 0.0002 & 0.0001 & 0.001 & 0.0001 \\
\hline
\end{tabular}




\begin{tabular}{|c|c|c|c|c|c|c|c|c|}
\hline $\mathrm{Pt}$ & 0.001 & 0.0003 & 0.0003 & 0.004 & 0.004 & 0.003 & 0.005 & 0.004 \\
\hline $\mathrm{Au}$ & 0.0005 & 0.0004 & 0.0003 & 0.024 & 0.024 & 0.022 & 0.019 & 0.025 \\
\hline $\mathrm{Hg}$ & 0.013 & 0.0055 & 0.0022 & 0.24 & 0.13 & 0.24 & 0.11 & 0.13 \\
\hline $\mathrm{Tl}$ & 0.044 & 0.070 & 0.051 & 0.0003 & 0.0001 & 0.0005 & 0.0003 & 0.0002 \\
\hline $\mathrm{Pb}$ & 0.143 & 0.234 & 0.156 & 0.072 & 0.032 & 0.151 & 0.069 & 0.062 \\
\hline $\mathrm{Bi}$ & 0.0006 & 0.0015 & 0.0009 & 0.005 & 0.005 & 0.027 & 0.009 & 0.004 \\
\hline Th & 0.0007 & 0.0006 & 0.0007 & 0.002 & 0.0006 & 0.0009 & 0.004 & 0.001 \\
\hline $\mathrm{U}$ & 0.81 & 0.44 & 0.44 & 0.08 & 0.05 & 0.21 & 0.16 & 0.03 \\
\hline
\end{tabular}

Note: 1-3 - Sredneobsky district crude oils: 1 - Povkhovskoye, well 3775/165, reservoir BV-8, interval 2684,6-2733, 2 - Vatjeganskoye, well 4881/106, interval 2607,82612; 3 - Yuzhno-Yagunskoye, well 164p, interval 2852,8-2858,6; 4-8 - Oktyabrsky district crude oil

During the normalization of trace elements contents in petroleum systems to the primitive mantle (according to [16]), the trends are very similar to the distribution in crude oils of the Shaim region (see Figure 1). On the Ni-Cu-Cr diagram proposed by A.A. Marakushev et al. [6] for resinous-asphaltene fractions, this crude oil belongs to the nickelchromium type (see Figure 2), falling into an intermediate region between the two types. Rare earth elements in the crude oils of the Sredneobsky region show the same distribution spectra as the hydrocarbons of the Shaim region - a gradual increase in light lanthanides, as well as the presence of a sharp positive europium anomaly and a weak negative one for samarium.

Oktyabrsky district. During the presented research we studied the oils of the Serginsky area. The deposit is located $16 \mathrm{~km}$ north of the city of Nyagan within the Oktyabrsky district of the Khanty-Mansi Autonomous Okrug. In total, eight samples of 
crude oils from various wells of the field were examined. The results of measurements are shown in table 2 (4-8). In the crude oil of the Oktyabrsky district, the group of trace elements is distinguished by relatively high contents (more than $1 \mathrm{ppm}$ ) of petrogenic components ( $\mathrm{Mg}, \mathrm{Al}, \mathrm{Fe}, \mathrm{Na}, \mathrm{Ti}, \mathrm{P}, \mathrm{Ca})$ and transit elements $(\mathrm{Cr}, \mathrm{Ni}, \mathrm{Zn})$. On the $\mathrm{Ni}-\mathrm{Cu}-\mathrm{Cr}$ diagram, this crude oil is of the nickel type (see Figure 2).

The rest of the trace elements in the crude oils of the Oktyabrsky district are characterized by low contents ( $<1 \mathrm{ppm}$; see Table 2$)$, but higher than in some rocks. For individual components ( $\mathrm{Ba}, \mathrm{Sr}, \mathrm{Zr}$, etc.), the content of elements in crude oils is quite comparable with their contents in ultrabasites. The amount of silver in the crude oil turned out to be lower than in the Shaim region (up to $0.05 \mathrm{ppm}$ ), and the amount of gold was significantly higher (no more than $0.025 \mathrm{ppm}$ ). Crude oil in the Oktyabrsky district has approximately the same PGE content, except for the rhodium content, where there is a large scatter of contents (by an order of magnitude) and in some wells in the contents of palladium and iridium, which differ by a factor of 10 or more. It is important to mention, that the trends in the distribution of platinoids in crude oils of Western Siberia have similar features and are usually characterized by the predominance of low-melting elements over refractory elements.

Rare earth elements in the crude oils of the Oktyabrsky region show the same distribution spectra as the hydrocarbons of the Shaimsky and Sredneobsky regions - a gradual increase in light lanthanides and the presence of a sharp positive europium anomaly.

\subsection{Inorganic geochemistry of Tatarstan crude oils}

We studied the crude oils of the Romashkinskoye, Bavlinskoye, Sarapalinskaya, Shiyskoye, Urustamakskoye oil fields of the Republic of Tatarstan $[5,8,10]$, while sampling of the crude oils was carried out under the guidance of Dr. Chem. Sciences G.P. Kayukova from the Institute of Organic and Physical Chemistry (city Kazan, Tatarstan, Russia).

The content of elements in the crude oils of Tatarstan is extremely low, except for certain components $(\mathrm{V}, \mathrm{Ni}, \mathrm{Cr}, \mathrm{Ca}, \mathrm{Sr}, \mathrm{Na}, \mathrm{Rb}, \mathrm{Cs}$, etc.). The general trend of trace elements is about two to three times below the level of the primitive mantle or chondrite. Tables 3 and 4 show the contents of trace elements in the oils of the Romashkinskoye oil field, Abdrakhmanovskaya and Berezovskaya areas, respectively. Crude oils of both areas are characterized by a single geochemical trend, differing in the contents of individual elements. So, for example, we have isolated high-strontium hydrocarbons with anomalous Sr content up to 55-63 ppm [5]. These hydrocarbons are confined to the reservoirs of the Upper Devonian deposits (wells Abd 13813, depth 1784-1798 m; Ber 21549, depth 1769-1773 m; Ber 21726, depth 1780.3-1782.2 m). These crude oils were in contact with gypsum-containing (sulfate) strata with a high content of celestine. This assumption is supported by the fact that, along with strontium, hydrocarbons are abnormally enriched in calcium (from 90 to $160 \mathrm{ppm}$ ). The rest of the crude oil samples are distinguished by extremely low strontium contents from $0.3 \mathrm{ppm}$ and below. In some cases, positive anomalies for rubidium, barium, and cesium appear, but only for highstrontium oils. In absolute concentrations, the concentrations for rubidium reach 2-2.5 ppm, and for cesium - 0.1-0.3 ppm and barium - up to $1.1 \mathrm{ppm}$. These are truly abnormal characteristics because the average content in crude oils (in ppm) is cesium 0.0043 and rubidium 0.015 . At the same time, the rest of the hydrocarbons are distinguished by lower concentrations for these elements in comparison with the average contents. Since rubidium, barium, and cesium form a direct dependence on strontium, we assume the presence of these components in crude oil in the form of a mechanical suspension of celestine or as a result of its dissolution. 
Table 3. Results of ICP-MS (in ppm) for crude oil of Abdrakhmanovskaya area (Romashkinskoye oil field)

\begin{tabular}{|c|c|c|c|c|c|c|}
\hline Crude oil & 880 & 3378 & 8855 & 9161 & 9189 & 13813 \\
\hline $\mathrm{Li}$ & 0.0530 & 0.0574 & 0.0733 & 0.0597 & 0.0506 & 0.2213 \\
\hline Be & 0.0279 & 0.0307 & 0.0086 & 0.0084 & 0.0332 & 0.0064 \\
\hline $\mathrm{Na}$ & 61.69 & 82.35 & 2.53 & 50.56 & 23.72 & 1663.96 \\
\hline $\mathrm{Mg}$ & 0.3174 & 0.4443 & 0.4757 & 0.2090 & 0.2732 & 56.7186 \\
\hline $\mathrm{Al}$ & 0.0429 & 0.0599 & 0.0754 & 0.0320 & 0.0354 & 0.0334 \\
\hline $\mathrm{Ca}$ & 1.1806 & 0.9907 & 0.4437 & 0.4875 & 0.9134 & 86.939 \\
\hline Sc & 0.0073 & 0.0052 & 0.0021 & 0.0035 & 0.0060 & 0.0026 \\
\hline $\mathrm{Ti}$ & 0.0198 & 0.0191 & 0.0143 & 0.0165 & 0.0212 & 0.0110 \\
\hline
\end{tabular}




\begin{tabular}{|c|c|c|c|c|c|c|}
\hline $\mathrm{V}$ & 3.4344 & 5.6396 & 7.9056 & 1.7543 & 2.0551 & 0.4228 \\
\hline $\mathrm{Mn}$ & 0.2543 & 0.2642 & 0.2166 & 0.2156 & 0.2733 & 0.1673 \\
\hline Co & 0.0337 & 0.0471 & 0.0666 & 0.0249 & 0.0247 & 0.0265 \\
\hline $\mathrm{Cr}$ & 1.44492 & 2.13491 & 1.86833 & 0.79234 & 1.33773 & 0.45182 \\
\hline $\mathrm{Ni}$ & 8.6413 & 16.1455 & 23.2513 & 4.0975 & 5.3161 & 1.2673 \\
\hline $\mathrm{Cu}$ & 0.1125 & 0.1126 & 0.0973 & 0.1069 & 0.1239 & 0.7588 \\
\hline $\mathrm{Zn}$ & 0.4241 & 0.5717 & 0.6946 & 0.3728 & 0.4137 & 0.4141 \\
\hline $\mathrm{Ga}$ & 0.0406 & 0.0518 & 0.0482 & 0.0163 & 0.0223 & 0.0796 \\
\hline Ge & 0.0295 & 0.0512 & 0.0582 & 0.0193 & 0.0295 & 0.0257 \\
\hline
\end{tabular}




\begin{tabular}{|c|c|c|c|c|c|c|}
\hline $\mathrm{Rb}$ & 0.0033 & 0.0044 & 0.0055 & 0.0028 & 0.0030 & 2.1222 \\
\hline $\mathrm{Sr}$ & 0.0865 & 0.0825 & 0.0848 & 0.0221 & 0.0205 & 63.676 \\
\hline Y & 0.0023 & 0.0027 & 0.0022 & 0.0008 & 0.0012 & 0.0015 \\
\hline $\mathrm{Zr}$ & 0.0157 & 0.0088 & 0.0049 & 0.0225 & 0.0226 & 0.0656 \\
\hline Mo & 0.0655 & 0.0503 & 0.0548 & 0.0522 & 0.0368 & 0.0379 \\
\hline $\mathrm{Ru}$ & 0.0022 & 0.0018 & 0.0010 & 0.0015 & 0.0023 & 0.0344 \\
\hline $\mathrm{Rh}$ & 0.0005 & 0.0006 & 0.0005 & 0.0003 & 0.0005 & 0.0091 \\
\hline $\mathrm{Pd}$ & 0.0027 & 0.0022 & 0.0017 & 0.0032 & 0.0034 & 0.0092 \\
\hline I & 0.6008 & 0.6355 & 0.8426 & 0.5459 & 0.4355 & 9.5521 \\
\hline
\end{tabular}




\begin{tabular}{|c|c|c|c|c|c|c|}
\hline $\mathrm{Ba}$ & 0.104319 & 0.156327 & 0.120545 & 0.008804 & 0.017109 & 0.56696 \\
\hline $\mathrm{La}$ & 0.001379 & 0.001688 & 0.001439 & 0.001481 & 0.001636 & 0.00129 \\
\hline $\mathrm{Ce}$ & 0.001782 & 0.002598 & 0.003124 & 0.001708 & 0.002487 & 0.00122 \\
\hline $\operatorname{Pr}$ & 0.000247 & 0.000349 & 0.000459 & 0.000178 & 0.000170 & 0.00020 \\
\hline $\mathrm{Nd}$ & 0.000959 & 0.001525 & 0.001711 & 0.000711 & 0.000724 & 0.00055 \\
\hline $\mathrm{Sm}$ & 0.000238 & 0.000371 & 0.000397 & 0.000155 & 0.000226 & 0.00011 \\
\hline $\mathrm{Eu}$ & 0.000367 & 0.000438 & 0.000392 & 0.000139 & 0.000185 & 0.00204 \\
\hline $\mathrm{Gd}$ & 0.000224 & 0.000351 & 0.000342 & 0.000140 & 0.000165 & 0.00009 \\
\hline $\mathrm{Tb}$ & 0.000043 & 0.000055 & 0.000052 & 0.000025 & 0.000031 & 0.000014 \\
\hline
\end{tabular}




\begin{tabular}{|c|c|c|c|c|c|c|}
\hline Dy & 0.000325 & 0.000337 & 0.000262 & 0.000160 & 0.000184 & 0.000079 \\
\hline Ho & 0.000066 & 0.000089 & 0.000059 & 0.000031 & 0.000033 & 0.000016 \\
\hline Er & 0.000182 & 0.000219 & 0.000161 & 0.000093 & 0.000074 & 0.000048 \\
\hline $\mathrm{Tm}$ & 0.000029 & 0.000030 & 0.000026 & 0.000012 & 0.000011 & 0.000009 \\
\hline $\mathrm{Yb}$ & 0.000206 & 0.000205 & 0.000156 & 0.000073 & 0.000070 & 0.000070 \\
\hline $\mathrm{Lu}$ & 0.000032 & 0.000034 & 0.000020 & 0.000010 & 0.000010 & 0.000010 \\
\hline Os & 0.000037 & 0.000049 & 0.000099 & 0.000117 & 0.000077 & 0.000315 \\
\hline Ir & 0.000069 & 0.000056 & 0.000019 & 0.000085 & 0.000197 & 0.000484 \\
\hline $\mathrm{Pt}$ & 0.004236 & 0.003606 & 0.000877 & 0.001545 & 0.005408 & 0.001278 \\
\hline
\end{tabular}




\begin{tabular}{|c|l|l|l|l|l|l|} 
& & & & & & \\
$\mathrm{Pb}$ & 0.041047 & 0.051704 & 0.096800 & 0.057565 & 0.038730 & 0.055446 \\
\hline $\mathrm{Th}$ & 0.000034 & 0.000048 & 0.000085 & 0.000033 & 0.000026 & 0.000104 \\
\hline & & & & & & \\
\hline $\mathrm{U}$ & 0.00447 & 0.00475 & 0.00512 & 0.01374 & 0.01351 & 0.08002 \\
\hline
\end{tabular}

Note: well 3378, D3 psh, 1764,8-1767,6 m; well 13813, D3 psh, 1784-1798 m; well 8855, D3 gv, 1816-1828 m; well 9189, D3 psh, 1624-1665 m; well 880, D3 psh; well 9161, 1691$1716 \mathrm{~m}$.

In addition, the oils of the Abdrakhmanovskaya and Berezovskaya areas show increased concentrations of petrogenic elements such as $\mathrm{Ca}, \mathrm{Al}, \mathrm{Fe}, \mathrm{Mn}, \mathrm{Na}$, and $\mathrm{Mg}$. We also have mentioned calcium in connection with high-strontium crude oils, in which the Ca content increases abnormally up to $160 \mathrm{ppm}$ (with the usual variation from 1 to 13 ppm). However, in the same crude oils, the concentration of sodium (from 700 to 2000 $\mathrm{ppm}$ ) and magnesium (from 50 to $70 \mathrm{ppm}$ ) increases sharply. The amount of these elements usually varies from 0.5 to $90 \mathrm{ppm}$ and from 0.2 to $0.6 \mathrm{ppm}$. As mentioned above, such a difference in grade may be since high-strontium crude oil was produced from sulfate-containing strata. The rest of the petrogenic components are characterized by lower contents - $\mathrm{Fe}$ (up to $10 \mathrm{ppm}$ ), $\mathrm{Mn}$ (up to $0.6 \mathrm{ppm}$ ), and $\mathrm{Al}$ (up to $2 \mathrm{ppm}$ ). For example, West Siberian crude oils are distinguished by even lower concentrations for manganese (up to $0.4 \mathrm{ppm}$ ), but high iron concentrations (up to $100 \mathrm{ppm}$ ) and aluminum (up to 9 ppm). This observation confirms the influence of the composition of reservoir rocks on the trace element composition of crude oil. In Western Siberia, the reservoirs are represented by terrigenous sediments, and in Tatarstan - carbonate ones. 
Table 4. Results of ICP-MS (in ppm) for crude oil of Berezovskaya area (Romashkinskoye oil field)

\begin{tabular}{|c|c|c|c|c|c|}
\hline $\begin{array}{c}\text { Crude oil } \\
\text { well }\end{array}$ & 101 & 651 & 7020 & 21549 & 21726 \\
\hline $\mathrm{Li}$ & 0.0662 & 0.0685 & 0.0622 & 0.1878 & 0.2825 \\
\hline $\mathrm{Be}$ & 0.0339 & 0.0378 & 0.0338 & 0.0251 & 0.0331 \\
\hline $\mathrm{Na}$ & 56.941 & 80.95 & 73.2647 & 2142.94 & 754.32 \\
\hline $\mathrm{Mg}$ & 0.3604 & 0.3068 & 0.6219 & 74.1416 & 56.0249 \\
\hline $\mathrm{Al}$ & 0.0473 & 0.0441 & 0.0835 & 0.0370 & 0.0417 \\
\hline $\mathrm{Ca}$ & 1.4430 & 1.7674 & 0.8314 & 162.9009 & 134.3230 \\
\hline Sc & 0.0090 & 0.0062 & 0.0037 & 0.0044 & 0.0031 \\
\hline $\mathrm{Ti}$ & 0.0267 & 0.0190 & 0.0184 & 0.0141 & 0.0149 \\
\hline $\mathrm{V}$ & 1.5766 & 1.5876 & 9.2609 & 0.4952 & 0.2531 \\
\hline $\mathrm{Mn}$ & 0.5469 & 0.4376 & 0.2745 & 0.2120 & 0.2834 \\
\hline
\end{tabular}




\begin{tabular}{|c|c|c|c|c|c|}
\hline Co & 0.0320 & 0.0253 & 0.0660 & 0.0263 & 0.0218 \\
\hline $\mathrm{Cr}$ & 1.677674 & 1.475283 & 3.154375 & 0.762833 & 0.465681 \\
\hline $\mathrm{Ni}$ & 6.2139 & 5.0081 & 30.1662 & 1.6442 & 1.4666 \\
\hline $\mathrm{Cu}$ & 0.2001 & 0.1960 & 0.1127 & 0.8791 & 1.1721 \\
\hline $\mathrm{Zn}$ & 0.5866 & 0.6530 & 0.7707 & 0.4595 & 0.3503 \\
\hline $\mathrm{Ga}$ & 0.0270 & 0.0288 & 0.0660 & 0.1090 & 0.0689 \\
\hline $\mathrm{Ge}$ & 0.0378 & 0.0296 & 0.0891 & 0.0393 & 0.0326 \\
\hline $\mathrm{Rb}$ & 0.0043 & 0.0041 & 0.0060 & 2.2861 & 2.4568 \\
\hline $\mathrm{Sr}$ & 0.0591 & 0.0471 & 0.0787 & 59.0816 & 55.2234 \\
\hline$Y$ & 0.0018 & 0.0016 & 0.0031 & 0.0022 & 0.0012 \\
\hline $\mathrm{Zr}$ & 0.0202 & 0.0190 & 0.0050 & 0.0661 & 0.0139 \\
\hline
\end{tabular}




\begin{tabular}{|c|c|c|c|c|c|}
\hline Mo & 0.0463 & 0.0262 & 0.0386 & 0.0267 & 0.0112 \\
\hline $\mathrm{Ru}$ & 0.0028 & 0.0008 & 0.0015 & 0.0521 & 0.0311 \\
\hline $\mathrm{Rh}$ & 0.0006 & 0.0005 & 0.0008 & 0.0155 & 0.0145 \\
\hline $\mathrm{Pd}$ & 0.0031 & 0.0028 & 0.0018 & 0.0098 & 0.0114 \\
\hline I & 7.0520 & 5.8137 & 0.6722 & 7.6204 & 9.1400 \\
\hline $\mathrm{Ba}$ & 0.044009 & 0.034264 & 0.234265 & 1.101832 & 0.931786 \\
\hline $\mathrm{La}$ & 0.001264 & 0.001652 & 0.001589 & 0.001432 & 0.000552 \\
\hline $\mathrm{Ce}$ & 0.001815 & 0.002100 & 0.003215 & 0.001365 & 0.001350 \\
\hline $\operatorname{Pr}$ & 0.000240 & 0.000321 & 0.000492 & 0.000195 & 0.000150 \\
\hline $\mathrm{Nd}$ & 0.000939 & 0.001133 & 0.002424 & 0.000791 & 0.000611 \\
\hline Sm & 0.000139 & 0.000142 & 0.000580 & 0.000161 & 0.000119 \\
\hline
\end{tabular}




\begin{tabular}{|c|c|c|c|c|c|}
\hline $\mathrm{Eu}$ & 0.000262 & 0.000217 & 0.000523 & 0.002724 & 0.002885 \\
\hline Gd & 0.000186 & 0.000162 & 0.000589 & 0.000158 & 0.000147 \\
\hline $\mathrm{Tb}$ & 0.000028 & 0.000031 & 0.000092 & 0.000027 & 0.000024 \\
\hline Dy & 0.000195 & 0.000196 & 0.000496 & 0.000182 & 0.000141 \\
\hline Ho & 0.000032 & 0.000035 & 0.000110 & 0.000039 & 0.000030 \\
\hline Er & 0.000091 & 0.000089 & 0.000263 & 0.000098 & 0.000092 \\
\hline $\mathrm{Tm}$ & 0.000015 & 0.000013 & 0.000035 & 0.000015 & 0.000017 \\
\hline $\mathrm{Yb}$ & 0.000093 & 0.000100 & 0.000208 & 0.000080 & 0.000095 \\
\hline $\mathrm{Lu}$ & 0.000015 & 0.000016 & 0.000031 & 0.000012 & 0.000015 \\
\hline Os & 0.000021 & 0.000019 & 0.000065 & 0.000207 & 0.000140 \\
\hline $\mathrm{Ir}$ & 0.000096 & 0.000106 & 0.000045 & 0.001115 & 0.000925 \\
\hline
\end{tabular}




\begin{tabular}{|c|c|c|c|c|c|} 
& & & & \\
$\mathrm{Pt}$ & 0.005476 & 0.003913 & 0.003069 & 0.004474 & 0.004193 \\
\hline $\mathrm{Pb}$ & 0.065294 & 0.067815 & 0.065128 & 0.037305 & 0.013907 \\
\hline $\mathrm{Th}$ & 0.000058 & 0.000057 & 0.000068 & 0.000083 & 0.000066 \\
\hline $\mathrm{U}$ & 0.004620 & 0.003645 & 0.005042 & 0.078692 & 0.070645 \\
\hline
\end{tabular}

Note: well 101, D3 gv, 1803,8-1826,6 m; well 651, C1 b, 1107,6-1113,2 m; well 7020, C1 tl, 1200,2 m; well 21549, D3 dm, 1769-1773 m; well 21726, D3 kn, 1780,3-1782,2 m.

The contents of rare earth elements in the crude oils of the Abdrakhmanovskaya and Berezovskaya areas of the Romashkinskoye oil field, normalized to chondrite, show one type of trend with a gradual enrichment of light lanthanides (see Fig. 4). The REE distribution spectrum is characterized by a $\mathrm{La} / \mathrm{Yb}$ ratio of up to 20 units with a positive or sharply positive europium anomaly. A sharp positive europium anomaly is characteristic of high-strontium crude oils from the Romashkinskoye field. In these samples, the europium content reaches $0.003 \mathrm{ppm}$, while in the rest it is no more than $0.001 \mathrm{ppm}$. The average content of this element in oil is defined as $0.00094 \mathrm{ppm}$, which is consistent with our experiments. Lanthanides form a direct relationship with each other, and an inverse relationship with europium, which reflects the geochemical anomaly of europium on the general REE trend. The spectrum of lanthanides in the studied petroleum systems is in good agreement with the data on the content of REE in asphaltenes from crude oils of the South Tatar arch, for which weak positive anomalies for europium were also established [2]. The positive europium anomaly was recorded in all samples. This, to some extent, confirms the prospects for the crude oil and gas content of the Tatar basement (see [10, etc.]), since, according to several Russian and foreign researchers, such anomalies are not characteristic of the upper crust formations and may indicate a deep (possibly mantle) origin of oil. [6, 18, etc.]. 


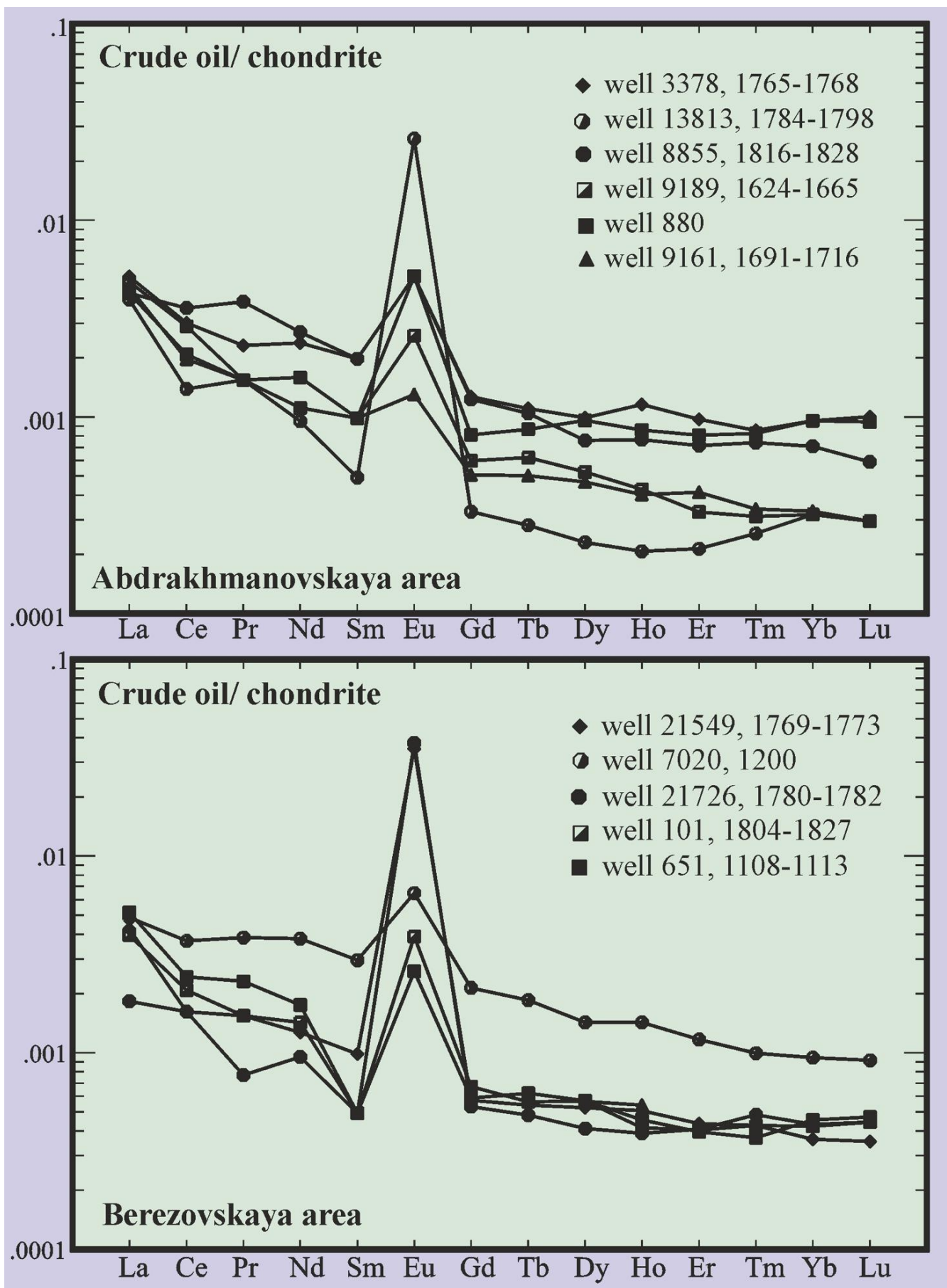

Figure 4. Distribution curves of rare earth elements normalized to chondrite [16] for crude oil from the Romashkinskoye oil field.

For West-Siberian crude oil, we have indicated a similar distribution of lanthanides with a positive anomaly for europium, except a weak negative anomaly for samarium. In general, the trends in the distribution of elements in West-Siberian naphthides are very similar to the spectra of crude oils from the Romashkinskoye field, even though they have significant differences [13].

Crude oils from different areas of Tatarstan form an almost unified geochemical trend (Figure 5). Three types of distribution are observed for strontium in hydrocarbons high-strontium (Sr content 55-63 ppm), medium-strontium, and normal-strontium (no anomalies). The first type is found only at the Romashkinskoye field in the Upper Devonian deposits (Abdrakhmanovskaya 13813, depth 1784-1798 m; Berezovskaya 21549, depth 1769-1773 m; Berezovskaya 21726, depth 1780.3-1782.2 m). These crude oils were produced from gypsum (sulfate) strata with a high content of celestine, since, along with 
strontium, hydrocarbons are abnormally enriched in calcium (from 90 to 160 ppm). The third type of oils is typical for Urustamak (well 303, ch. 1811-1814), Romashkinskiy (Abdrakhmanovskaya - well 9189, ch. 1624-1665 and well 9161, ch. 1691-1716), and Sarapalinskiy (well 2896, Kizelovskiy horizon; well 2907, Kizelovsky horizon; well 3016, Bobrikovsky horizon) fields. They contain extremely low strontium contents (less than $0.06 \mathrm{~g} / \mathrm{t}$ ). The rest of the oil we analyzed (most of the analyzes) belongs to the second type with $\mathrm{Sr}$ content up to $0.3 \mathrm{~g} / \mathrm{t}$. The abnormal strontium and calcium contents in oil can be explained by the presence of a mechanical suspension of celestine and gypsum since these elements form a direct relationship with each other.

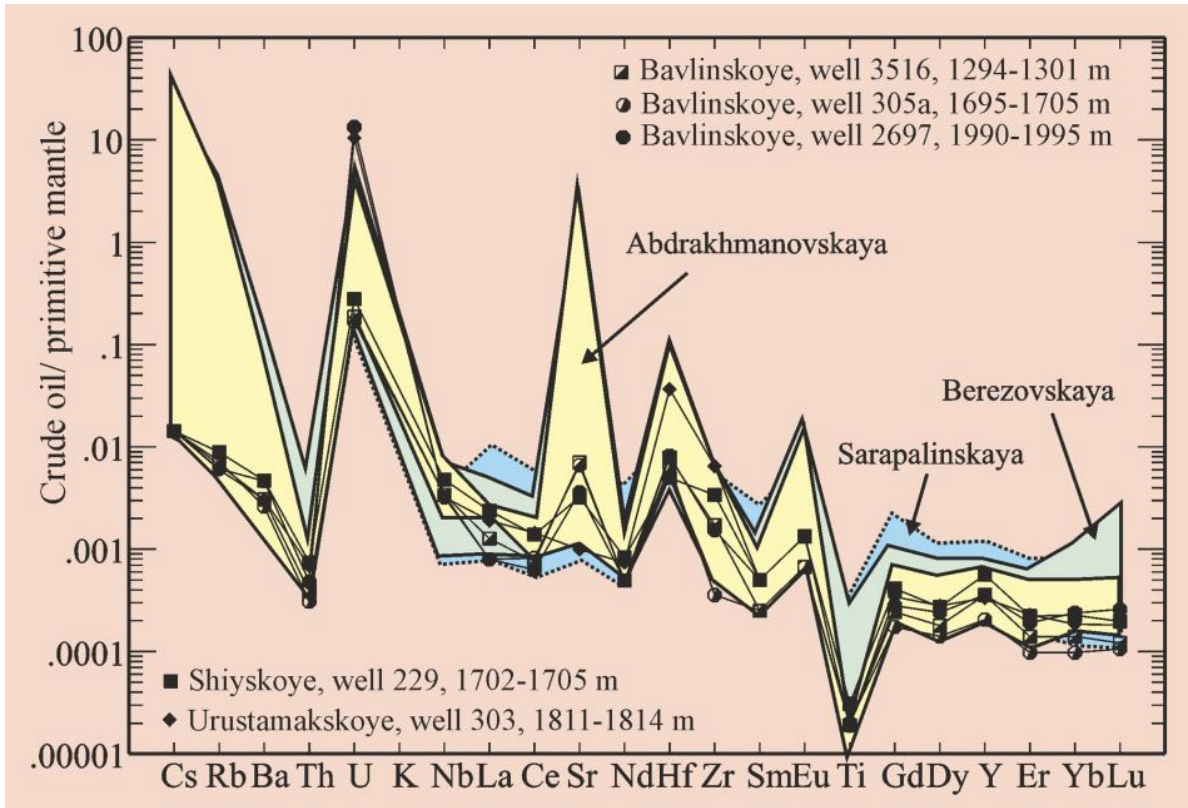

Figure 5. Spider-diagram normalized by the primitive mantle composition [18] for crude oil of Tatarstan.

The nickel content in the studied crude oils, despite the absence of a geochemical anomaly, reaches $30 \mathrm{ppm}$, which is quite comparable with other data on the deposits of Tatarstan and the whole world. For example, the metal content in the crude oils of Canada does not exceed 9 ppm, and in Libya - 50 ppm (in the same West Siberian deposits, the amount of nickel reaches $17 \mathrm{ppm}$ ). Thus, on the $\mathrm{Ni}-\mathrm{Cu}-\mathrm{Cr}$ diagram for the resinousasphaltene fractions, the Tatarstan oil belongs to the nickel type (see Figure 2), while the West Siberian oil belongs to the chromium type.

An interesting and rather unexpected fact was the significant presence of platinoids (Pt, Ir, Os, Ru, Rh, Pd) in the oils of the Romashkinskoye field, especially ruthenium and rhodium. In total, their amount varies from 0.01 to $0.08 \mathrm{ppm}$ (the concentration of ruthenium sometimes reaches $0.06 \mathrm{ppm}$ ), which is slightly lower than in meteorites, but higher than in many rocks of the Earth (according to [3]). For example, in West Siberian oils, the total amount of platinoids is much lower (they do not exceed $0.01 \mathrm{ppm}$ ). When normalized to chondrite [15], the distribution of platinoids shows a smooth decrease from ruthenium to platinum with a negative anomaly in the region of iridium and osmium; ruthenium-rhodium specialization is established for oil from the Romashkinskoye field (see Figure 6). For example, West Siberian oils are characterized by palladium specialization with a negative anomaly in the iridium area. In general, the trend of the content of platinoids in crude oils is quite different from that of the resinous-asphaltene fractions, according to [6], but it is quite comparable in terms of the concentration level. For the elements of the palladium group, similar contents are still noted, and for the platinoids, lower concentrations are observed in oil. 


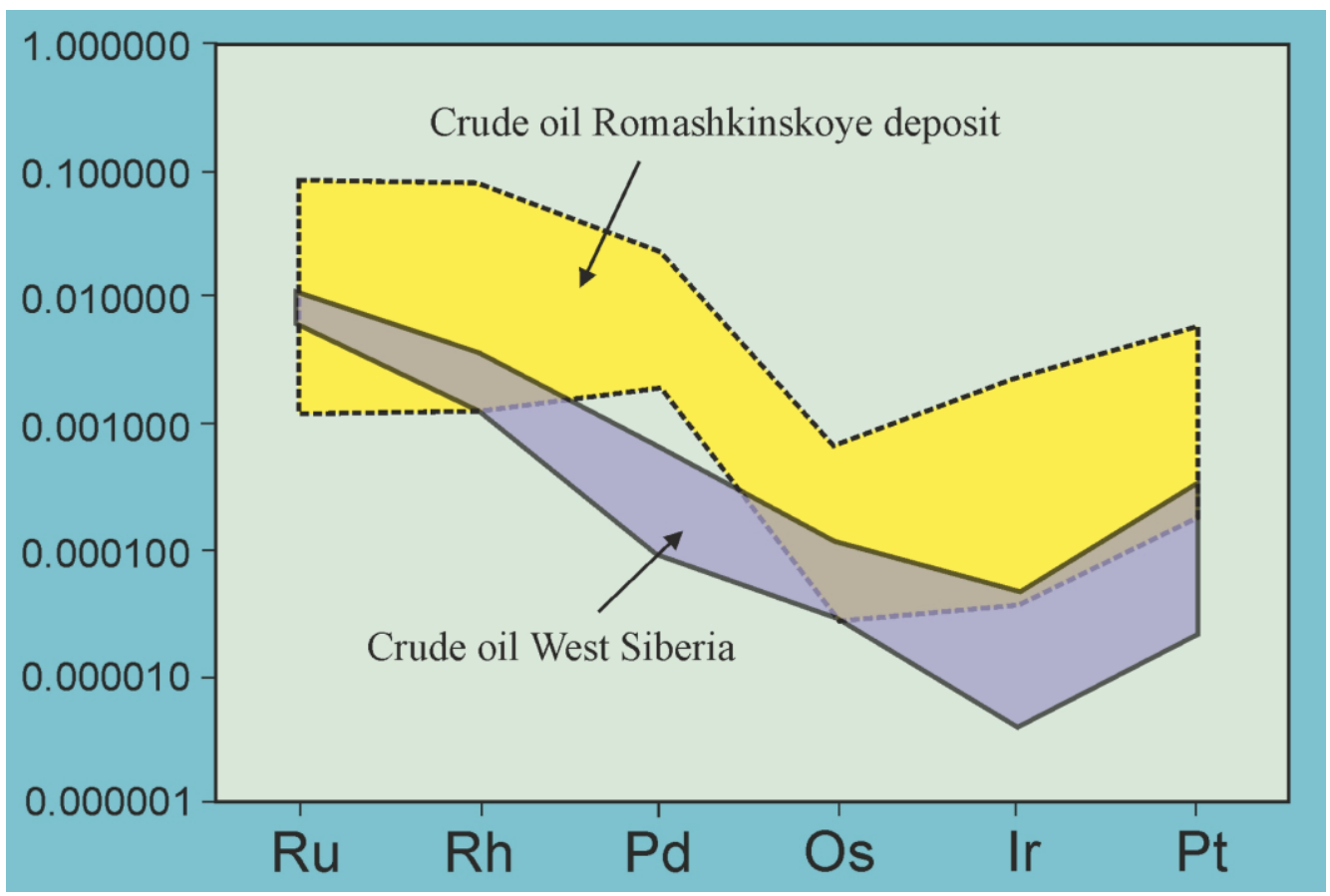

Figure 6. Distribution of platinoids in crude oils of the Romashkinskoye deposit and Western Siberia.

Taking into consideration the elevated amount of transit elements ( $\mathrm{Ni}, \mathrm{Co}, \mathrm{Cr}, \mathrm{V}$, etc.) and platinoids, it was previously concluded [6, etc.] about the "ultrabasic" geochemicalmetallogenic specialization of crude oil, and then it was proposed that crude oils could have the mantle origin [19]. The revealed geochemical features of crude oils can also be partly explained by the biogenic hypothesis of its origin (however, with bigger assumptions), according to which crude oil and hydrocarbons in the Earth's crust are formed from organic substances - kerogen and bitumoids. The catalysts of this process, most likely, are the host rocks (mainly clays), as well as some metals such as $\mathrm{Ni}$, Pt. In other words, the geochemical specialization of oil is precisely determined by the catalyst metals that could be accumulated in the hydrocarbon systems. Noting the special features of petroleum inorganic geochemistry, recently it has shown that geochemistry of crude oils could be dual - there are both traces of its deep origin and its interaction with sedimentary rocks $[20,21]$

\section{Conclusions}

The study of the inorganic geochemistry of West-Siberian and Tatarstan crude oils using the most modern equipment shows that crude oils (at least from these two provinces, and, apparently, others) have an extremely specific microelement composition with no comparisons.

The main geochemical feature of crude oil is the extremely low content of most trace elements. The second geochemical feature of crude oil is a constant and pronounced positive europium anomaly. According to [18], a positive europium anomaly could be a characteristic of deep genesis which means that crude oil could be formed in the lower parts of the earth's crust and below.

Based on the increased contents of some transit elements ( $\mathrm{Ni}, \mathrm{Co}, \mathrm{Cr}, \mathrm{V}$, etc.) and platinoids, several reputable scientists also concluded that the crude oil is of "ultrabasic" geochemical-metallogenic specialization [6]. 
The presented study is pioneering in many ways, the conclusions obtained are based on a relatively small amount of data so far (the total number of our ICP-MS analysis of crude oils is around a hundred). The study of inorganic geochemistry of crude oils by the ICP-MS method should be continued, especially bearing in mind the difficulties arisen, associated with very low contents and (in some cases) insufficiently good reproducibility of single analyzes.

Many geologists and geochemists, while performing various geochemical analyzes as well as building graphs, triangular petrodiagrams, etc., could forget that every analysis has its errors. And when it is said, $\pm 8-10 \%$, then in some cases it is still relevant (for many elements, the ICP-MS method allows an error of $25-30 \%$ ). That means that every point on the diagram is not a point, it is a field that increases with the error probability.

In addition, experience has shown that many geochemical laboratories are reluctant to undertake ICP-MS analysis of crude oil. This is due to both reluctance to master a new technique (especially if the forthcoming volume of analyzes is unclear), and to the fact that crude oils are highly volatile substances and can give significant "pollution" of ultraclean rooms in which the analysis is carried out. In connection with all of the above, we note that not all of our initial hopes for the widespread use of ICP-MS analysis of crude oil were justified (for example, for the strict identification of oils from neighboring deposits by this method, for example, for sharing production or to find out who is to blame for the oil spill).

Nevertheless, our main conclusions, including genetic ones, most likely, will not undergo any changes. It is important to note that the introduction of the ICP-MS method marks the new era beginning of inorganic crude oil geochemistry. The high sensitivity of the method, achieved with the use of high-resolution mass spectrometers with doublefocusing, made it possible to increase the number of elements determined directly in crude oil up to 70 (instead of the traditional 15-20).

Author Contributions: Conceptualization, Ivanov K.S.; Methodology, Ivanov K.S. and Erokhin Yu.V..; Software, Erokhin Yu.V. and Kudryavtsev D.A.; Validation, Ivanov K.S., Erokhin Yu.V. and Kudryavtsev D.A..; Formal Analysis, Ivanov K.S., Erokhin Yu.V. and Kudryavtsev D.A.; Investigation, Ivanov K.S. and Erokhin Yu.V.; Resources, Ivanov K.S.; Data Curation, Ivanov K.S. and Erokhin Yu.V.; Writing - Original Draft Preparation, Ivanov K.S. and Erokhin Yu.V.; Writing Review \& Editing, Kudryavtsev D.A.; Visualization, Erokhin Yu.V. and Kudryavtsev D.A.; Supervision, Ivanov K.S.; Project Administration, Ivanov K.S.; Funding Acquisition, Ivanov K.S.

Funding: These studies were carried out within the framework of the state budgetary theme of the Institute of Geology and Geochemistry of the Ural Branch (registration number AAAA-A18118052590032-6).

Acknowledgments: For substantial help and discussion of the results, we express our gratitude to Yu.N. Fedorov, K.Sh. Biglov, O.P. Lepikhina, G.P. Kayukova, I.N. Plotnikova, Yu.L. Ronkin, L.I. Svechnikov, M.R. Yakupov.

Conflicts of Interest: The authors declare no conflict of interest.

\section{References}

1. Author 1, A.; Author 2, B. Book Title, 3rd ed.; Publisher: Publisher Location, Country, 2008; pp. 154-196.

2. Alekseev V.P., Fedorov Yu.N., Gazaleev S.S., Russian V.I., Svechnikov L.I., Khakimov A.F. History of the formation of deposits of the Tyumen suite of the Shaim oil and gas region // Geologiya ugol'nykh depositov- Geology of coal deposits. - Yekaterinburg: Publishing house of USMU. 2004. Issue. 14. P. 130-139.

3. Vinokurov S.F., Gottikh R.P., Pisotsky B.I. Complex analysis of the distribution of lanthanides in aphaltenes, waters and rocks to clarify the conditions for the formation of oil fields // Doklady Akademii Nauk - Reports of the Academy of Sciences. 2000,V. 370. No. 1. P. 83-86.

4. Voitkevich G.V., Miroshnikov A.E., Povarenykh A.S., Prokhorov V.G. A short guide to geochemistry. Moscow: Nedra, 1970. 280 p. 
5. Ivanov K.S., Kormiltsev V.V., Fedorov Yu.N. et al. The main features of the structure of the pre-Jurassic basement of the Shaim oil and gas region // Ways of realizing the oil and gas potential of the Khanty-Mansi Autonomous Okrug. Sixth scientific and practical conference. Khanty-Mansiysk, 2003. V. 1. P. 102-113.

6. Ivanov K.S., Erokhin Yu.V., Ronkin Yu.L., Plotnikova IN, Kayukova G.P. Inorganic geochemistry of oil from the Romashkinskoye field - the first results of research using the ICP-MS method // Proceedings of the conference "Hydrocarbon potential of the basement of young and ancient platforms." Kazan: KazGU Publishing House, 2006. P. 100-103.

7. Marakushev A.A., Pisotsky B.I., Paneyakh N.A., Gottikh R.P. Geochemical specificity of oil and the origin of its deposits // Doklady Akademii Nauk - Reports of the Academy of Sciences. 2004. V. 398. No. 6. P. 795-799.

8. Nadirov N.K., Kotova A.V., Kamyanov V.F. and others. New oils of Kazakhstan and their use: Metals in oils. Alma-Ata: Science, 1984.

9. R.Kh. Muslimov. Oil and gas potential of the Republic of Tatarstan. Geology and development of oil fields. V. 1. Ed. Kazan: publishing house "Feng" of the Academy of Sciences of the Republic of Tatarstan, 2007.

10. Features of the geological structure and development of deposits in the Shaim oil and gas region. Collection of scientific articles. Urai-Tyumen, $2002.283 \mathrm{p}$.

11. Plotnikova I.N. Geological-geophysical and geochemical preconditions for the oil and gas potential of the crystalline basement of Tatarstan. Saint Petersburg: Nedra, 2004.146 p.

12. Fedorov Yu.N., Alekseev V.P., Ivanov K.S., Pecherkin MF, Svechnikov LI New geological data and prospects for the growth of active oil reserves in the Shaim region // Oil industry, 2004. No. 6. P. 22-25.

13. Fedorov Yu.N., Ivanov K.S., Erokhin Yu.V., Ronkin Yu.L. Inorganic oil geochemistry of the Shaim region (West Siberian oil and gas megabasin) // Collection "Ways of realizing the oil and gas potential of the Khanty-Mansi Autonomous Okrug-Yugra". KhantyMansiysk, 2006. V. 1. P. 306-314.

14. Fedorov Yu.N., Ivanov K.S., Erokhin Yu.V., Ronkin Yu.L. Inorganic geochemistry of oil in Western Siberia (the first results of the study by the ICP-MS method) // Doklady Akademii Nauk - Reports of the Academy of Sciences. 2007. V. 414. No. 3. P. 385-388.

15. Fish R.M., Komlenic J.J. Molecular characterization and profile identification of vanadil compounds in heavy crude petroleum by liquid chromatography/graphite furnace atomic absorption spectrometry // Analytical Chemistry. 1984. V. 56. № 3. P. 24522460.

16. Naldrett A.J., Duke J.M. Platinum metals in magmatic sulfide ores // Science. 1980. V. 208. P. 1417-1424.

17. Nakamura N. Determination of REE, Ba, Fe, Mg, $\mathrm{Na}$ and $\mathrm{K}$ in carbonaceous and ordinary chondrities // Geochim. Cosmochim. Acta. 1974. V. 38. P. 757-775.

18. Pearcon C.D., Green J.B. Comparison of processing characteristics of Magan and Wilmington heavy residues. Characterization of vanadium and nickel complexes in acid-base-neutral fractions // Fuel. 1989. V. 68. № 4. P. 465-468.

19. Taylor S.R., McLennan S.M. The continental crust: its composition and evolution. Blackwell, Oxford. 1985. 312 p.

20. Ivanov K.S., Kucherov V.G., Fedorov Yu.N. On the question of the deep origin of oil // State, trends and problems of development of oil and gas potential of Western Siberia. Tyumen: ZapSibNIIGG, 2008. P. 160-173.

21. Rodkin M.V., Rundkvist D.V., Geofluidodynamics - applications to seismology, tectonics and the processes of ore and petroleum formation. Dolgoprudniy: RFFI, 2017.

22. Rodkin M.V., Rundkvist D.V., Punanova S.A. The relative role of lower and upper crustal processes in the formation of trace element compositions of oils. Geochemistry International. 2016. N. 54. V. 11. P. 989-995. 